Technical Report

\title{
Development of the Model to Estimate Amount and Availability of Logging Residues Using Forest Management Records in Tochigi Prefecture
}

\author{
Reiko YAMAGUCHI ${ }^{* 1}$, Kazuhiro ARUGA* ${ }^{\text {, }}$, and Mayu NAGASAKI*2 \\ (Received April 27, 2011)
}

\author{
栃木県における森林施業履歴を用いた林地残材発生量と収穫可能量推定モデルの構築 \\ 山口鈴子*1，有賀一広*1，長崎真由*2
}

\begin{abstract}
In Tochigi prefecture, some facilities to demand woody biomass resources such as the biomass power plant, chip production factories, and the pellet plant are located. These raw materials are mainly supplied by sawmill residues and construction wastes. However, since the number of entrepreneurs who set up the biomass power plants as a measure against climate change, it is worried about stringent supplies of those materials. Therefore, unused materials such as logging residues must be harvested and used near the future. In the previous study, we developed a method to estimate the harvesting volumes and costs of logging residues from subcompartments with plus balances, including both timber and logging residue harvesting at Sano city, Tochigi prefecture. In this study, we estimated the harvesting volumes and costs of logging residues for all cities and towns in Tochigi prefecture. Three factories in Sano city, Kanuma city, and Nasushiobara city, Tochigi prefecture were assumed as destinations, and set of the harvesting operation system based on each forestry cooperative. In addition, the previous study estimated these volumes and costs in whole city of Sano, but this study estimated these volumes and costs using forest management records. This could estimate these volumes and costs based on actual forest operations in this area. The model estimated these volumes and costs in the following order. 1) Selecting subcompartments conducting pre-commercial or commercial thinning operations from forest management records, 2) Setting extracting rates for timber and logging residues, 3) Estimating harvesting volumes of timber and logging residues, 4) Estimating logging distances, transporting distances, and inclinations of operation sites, 5)Estimating total expenses, 6) Estimating incomes, 7) Estimating economic balances, 8) Estimating harvesting volumes from subcompartments with plus balances. The amount of logging residues from subcompartment with plus balances were 581 ton on the price of logging residues in this area: 3,000 yen/ton. If Feed-in Tariff (FIT) was established, the price of logging residues would be 10,000 yen/ton and the amount of logging residues from subcompartment with plus balances would be 134,198 ton/year which were almost equal to the demand of this area. The whole tree logging system may be more advantageous than the cut-to-length system for extracting logging residues.
\end{abstract}

\section{Key Words}

Logging residues, GIS, Forest management records, Harvesting operation system

1. はじめに

栃木県の森林は, 森林面積 349,228 ha で県土の $54.5 \%$ を占 めている。そのうち人工林は 156,763 ha で, 県内の全森林面 積の $44.9 \%$ を占め, 人工林の蓄積は $42,255,000 \mathrm{~m}^{3}$ で, 県内の

* 1 Department of Forest Science, Faculty of Agriculture, Utsunomiya University

350 Mine, Utsunomiya-shi, Tochigi 321-8505, Japan

* 2 Japan wood energy Co., Ltd.

5-10-1 Kawabe, Oume-shi, Tokyo198-0036, Japan
全森林蓄積の $62.4 \%$ を占める1)。これら人工林で深刻になった 間伐遅れに対応するため, 栃木県では, 平成 20 年 4 月より導 入した「とちぎの元気な森づくり県民税」の実施事業の中で, 「奥山林整備事業」を開始した。その平成21年度実績は652,978

\footnotetext{
* 1 宇都宮大学農学部森林科学科

₹ 321-8505＼cjkstart杤木県宇都宮市峰町 350

*2 森のエネルギー研究所

干 198-0036 東京都青梅市河辺町 5-10-1
} 
千円で，全事業費 1,013,339 千円の $64.4 \%$ を投入し，2,663 ha の間伐を実施した。しかし，採算性の問題から伐捨間伐の手 法がとられており，県内の間伐実施面積が増加する一方で，多 量の林地残材が発生し，森林内に資源が残されている2)。

一方で，佐野市，鹿沼市，那須塩原市等で木質バイオマス を主燃料とする発電所，チップ生産工場，ペレット製造工場 等が建設され，稼動している。小規模な民間施設も加えると， さらに多くの木質バイオマスの需要があり, さらに今後も木 質バイオマスの需要が増加していく可能性がある。これらの 需要を満たすためには今後，未利用の林地残材を活用する必 要性も生じ，未利用の林地残材の活用を検討するためには，ま ずは県内に打ける間伐，主伐作業による林地残材の発生量お よび発生場所を把握し，さらに収穫費用，収入，収支を試算 し，林地残材の利用可能量を検討する必要がある。そして，適 正な買取価格や補助事業の形態，利用間伐や路網整備の促進 などによる効率的な収穫作業による費用の低減化等の可能性 を検討する必要がある。

このような背景を受けて，筆者らは佐野市を対象として，森 林簿や森林計画図を用いて，小班単位で用材と林地残材の収 穫費用と収入を試算し，収支を比較することにより，経済性 が成り立つ林地からの林地残材の収穫量, 収穫費用を試算す るモデルを佐野市内全域のスギ，ヒノキ人工林を対象に構築 した ${ }^{3)}$ 。

本調査では，前報の研究を栃木県全域に拡張するとともに， 平成 20 年度の施業履歴を用いることにより，単年度の林地残 材発生量を推定し，さらに費用算定式を用いて収穫費用を試 算し，想定した買取価格と比較し，経済性が成り立つ林地か ら搬出される林地残材を収穫可能量として推定した結果を報 告する。なお，本調査は栃木県の「緑の分権改革」推進事業 における栃木県クリーンエネルギー賦存量及び利用可能量等 調査内, 森林バイオマス（林地残材）賦存量及び利用可能量 詳細調査で行われたものである。

\section{2. 調査地}

本調査で対象としたのは，民有林のスギ・ヒノキ人工林で， 森林簿から集計したその面積は，113,947 haである。今回用い た平成 20 年度の施業履歴から, 間伐が実施された全対象地 （広葉樹林を約 1 \%含む）は 5,100 haで，全 27 市町のうち 19 市町で間伐が実施された（図 1 )。

発生した林地残材の般出先として, (1)佐野市内のチップ生 産工場（木質バイオマス年間需要量 100,000 七うち林地残材 年間需要量 6,000 t) ${ }^{4}$, (2)鹿沼市内のチップ生産工場 (年間チッ プ生産量 $\left.12,000 \mathrm{~m}^{3}\right)^{5)}$ ，(3)那須塩原市内のペレット製造工場 （原木年間需要量 $3,000 \mathrm{t}$ 程度）の 3 施設を想定した。

\section{3. 調查方法}

栃木県庁より提供された施業履歴の間伐実績から，間伐に よる林地残材発生量を推定し，その収穫費用を試算する。さ らに買取価格を設定し，林地残材によって得られる収入を算 出，収支比較によって収支プラスとなった林地残材発生量分 を林地残材収穫可能量とする。

試算手順は，1. 間伐実施小班の検索，搬出の有無による施 業区分（伐捨間伐，利用間伐)，2. 搬出率，材種率の設定，3. 林地残材発生量の推定，4. 林地傾斜，搬出距離，運搬距離の 算出，5. 林地残材収穫直接費の算出，6. 林地残材買取価格の 設定，収入の算出， 7. 収支比較，林地残材収穫可能量の推定 の順に行う。また，解析は $50 \mathrm{~m} \times 50 \mathrm{~m}$ のラスターベースで 行い，伐出などは小班単位で行うと仮定して計算した。

3.1 間伐実施小班の検索，搬出の有無による施業区分（伐 捨間伐，利用間伐)

施業履歴から，平成20年度に実施された森林施業とその小 班位置を特定し，この実施された施業の中から間伐が行われ た小班について，その般出の有無から施業区分(伐捨間伐，利 用間伐）を行った（図1）。なお，分布図について，栃木県全

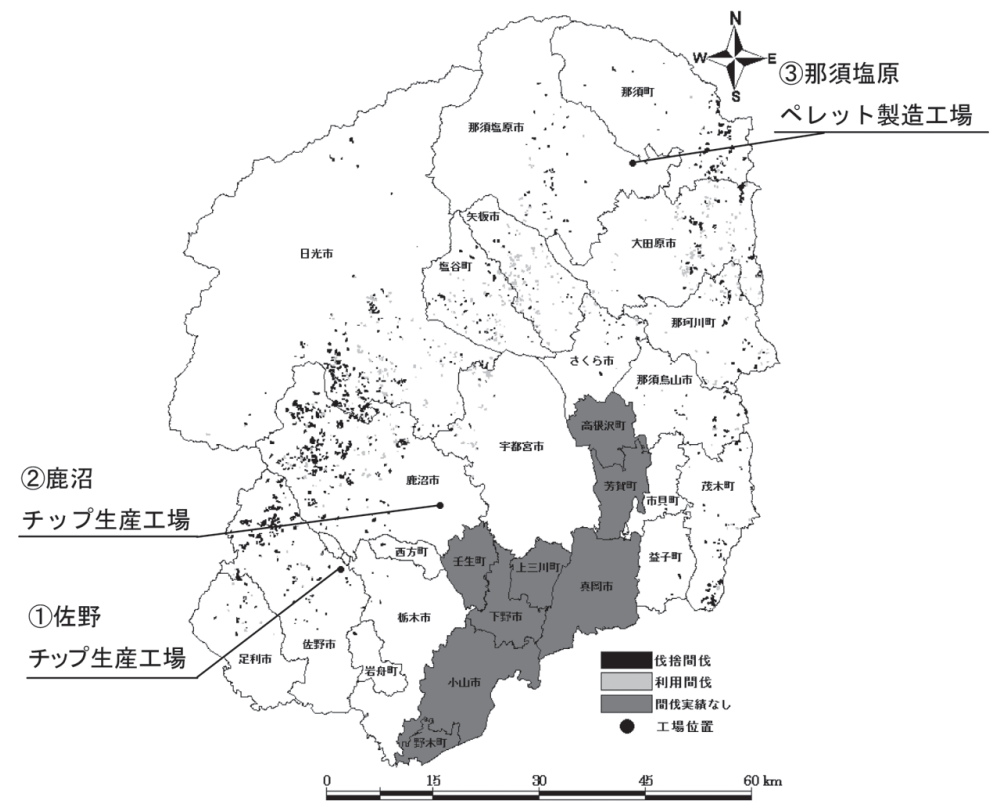

図 1 間伐施業区分分布図（ポイントを約 10 倍で強調） 


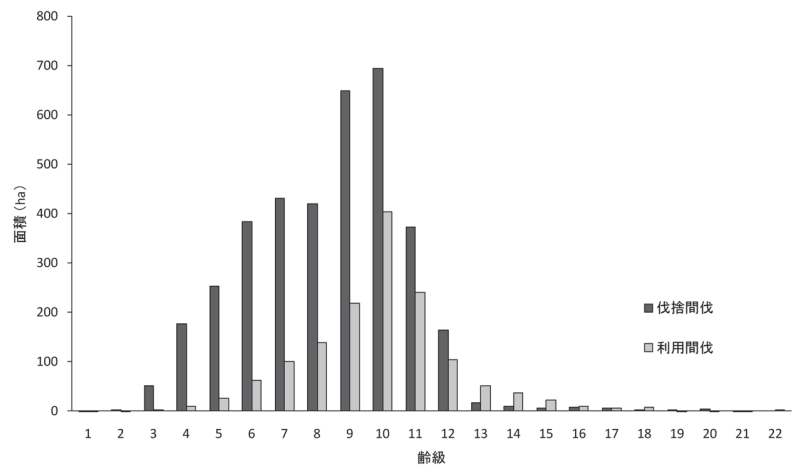

図 2 間伐施業区分頻度分布

土に対する間伐実施小班が非常に小面積であるため, 小班を 判別しやすくする手法として，ポイントを約10倍に強調し作 成した。施業区分は搬出ありの小班を利用間伐実施小班，搬 出なしもしくは搬出不明の小班を伐捨間伐実施小班とする。 図 2 に施業区分の頻度分布を示す。林齢が 60 年 (12 齢級) を 超えるような林分においても伐捨間伐がされており，利用間 伐は全体の約 $28 \%$ である。伐捨間伐，利用間伐の割合は市町 によって特徵があり, 利用間伐割合が $50 \%$ を超える市町は, 宇都宮市 $82 \%$ ，矢板市 $76 \%$ であった。

\section{2 搬出率, 材種率の設定}

伐採した材のうち搬出する割合を搬出率Erとして，スギで $123 \%$ ，ヒノキで124\%と設定した。これは枝条も含めた林地 残材発生量とするために，「とちぎカーボンオフセット」で利 用されている日本国温室効果ガスインベントリ報告書 ${ }^{6}$ から, 樹種別バイオマス拡大係数 BEF（蓄積（立木の幹部）に対す る枝条も含めた地上部材積比率) のスギ 1.23 , ヒノキ 1.24 を 用い，枝条部分を搬出材積に計上したものである。

また，伐採，搬出した材のうちチップ生産工場やペレット 製造工場へ運搬する材の割合を材種率 $(\mathrm{C} \cdot \mathrm{D}$ 材) $L r$ ，通常用 材とする材の割合を材種率 $(\mathrm{A} \cdot \mathrm{B}$ 材) として，蓄積（立木の 幹部）に対して伐捨間伐で $90 \%$ と $10 \%$ ，利用間伐で $50 \%$ ずつ と設定したため, 地上部材積に対して材種率は表 1 の通りと なる。

\section{3 林地残材発生量の推定}

林地残材発生量 $H L(\mathrm{t})$ の推定は, 森林簿に記載された各小 班の総材積量 $S\left(\mathrm{~m}^{3}\right)$ に, 伐採率 $C r$, 搬出率 $E r$ を乗じて小班 からの全発生量 $H\left(\mathrm{~m}^{3}\right)$ を求め, これに材種率 $(\mathrm{C} \cdot \mathrm{D}$ 材 $) \mathrm{Lr}$
表 2 事業区分ごと平均伐採率

\begin{tabular}{lc}
\hline & 平均伐採率 (\%) \\
\hline 造林事業 & 24 \\
治山事業 & 28 \\
保安林整備事業 & 29 \\
県営林事業 & 29 \\
税事業 (奥山 A) & 29 \\
税事業 (奥山 B) & 29 \\
\hline
\end{tabular}

と容積比重 $G r$ を用いて算出した。容積比重 $G r$ はみかも森林 組合が調査で算出した $0.68 \mathrm{t} / \mathrm{m}^{3}$ を用いた ${ }^{7)}$ 。

伐採率Crに関して，施業履歴に記録がある場合はその值を 用い，ない場合は事業区分ごとの平均伐採率（表 2 ）を伐採 率Crとして用いた。事業区分ごと平均伐採率は, 間伐実績の データ元が各補助事業の記録であることから，各補助事業で 行われた間伐について，その伐採率を平均したものである。

$$
\begin{aligned}
& H=S \times C r \times E r \\
& H L=H \times L r \times G r
\end{aligned}
$$

\section{4 林地傾斜, 搬出距離, 運搬距離の算出}

小班の林分条件として，小班内の土場と林分の標高差から 林地傾斜 (図 3 ) を, 土場と林分の平均距離から搬出距離 (図 4 ）を, 土場から想定した利用施設までの最短距離から運搬 距離を，それぞれ算出する。土場の設定は，小班内で1)林道, 2)小班の重心，3)利用施設のいずれからも最短となるセルを 土場と仮定した。

規模の大きいチップ生産工場への搬出は，全19市町でより 近い工場へ搬出することを想定して試算した。規模の小さい ペレット製造工場への搬出は，年間原木受入量を 3,000 tまで とし, 周辺地域の那須塩原市, 大田原市，那須町の 3 市町を 対象に収穫費用の低い小班から順に収穫し, 収穫量が 3,000 t を超えた時点でペレット製造工場への搬出は終了, 残りの小 班で発生した林地残材はチップ生産工場へ搬出すると想定し 試算した。チップ生産工場への運搬距離を比較した結果，栃 木市, 西方町, 鹿沼市, 日光市において, 小班位置による工 場選択の可能性があることがわかった。

\section{5 林地残材収穫直接費の算出}

収穫作業システムは, 県内森林組合への聞き取り調査を参 考に，森林組合毎に代表的な収穫作業システムを $1 \sim 2$ 種設 定した。表 3 に設定した収穫作業システムとその採用森林組

\begin{tabular}{|c|c|c|c|c|c|c|}
\hline & \multicolumn{2}{|c|}{ 伐捨間伐 } & \multicolumn{2}{|c|}{ 利用間伐 } & \multirow{2}{*}{$\begin{array}{c}\text { 主伐 } \\
\text { スギ・ヒノキ }\end{array}$} \\
\hline & & スギ & ヒノキ & スギ & ヒノキ & \\
\hline \multicolumn{2}{|c|}{ 搬出率 } & $123.0 \%$ & $124.0 \%$ & $123.0 \%$ & $124.0 \%$ & $123.4 \%$ \\
\hline \multirow{3}{*}{$\begin{array}{c}\text { 材種率 } \\
(\mathrm{C} \cdot \mathrm{D} \text { 材 })\end{array}$} & 幹部 & $73.2 \%$ & $72.6 \%$ & $40.7 \%$ & $40.3 \%$ & $20.2 \%$ \\
\hline & 枝葉部 & $18.7 \%$ & $19.4 \%$ & $18.7 \%$ & $19.4 \%$ & $19.0 \%$ \\
\hline & 計 & $91.9 \%$ & $91.9 \%$ & $59.3 \%$ & $59.7 \%$ & $39.2 \%$ \\
\hline \multicolumn{2}{|c|}{ 材種率 $(\mathrm{A} \cdot \mathrm{B}$ 材 $)$} & $8.1 \%$ & $8.1 \%$ & $40.7 \%$ & $40.3 \%$ & $60.8 \%$ \\
\hline
\end{tabular}

表 1 施業区分毎の条件設定 


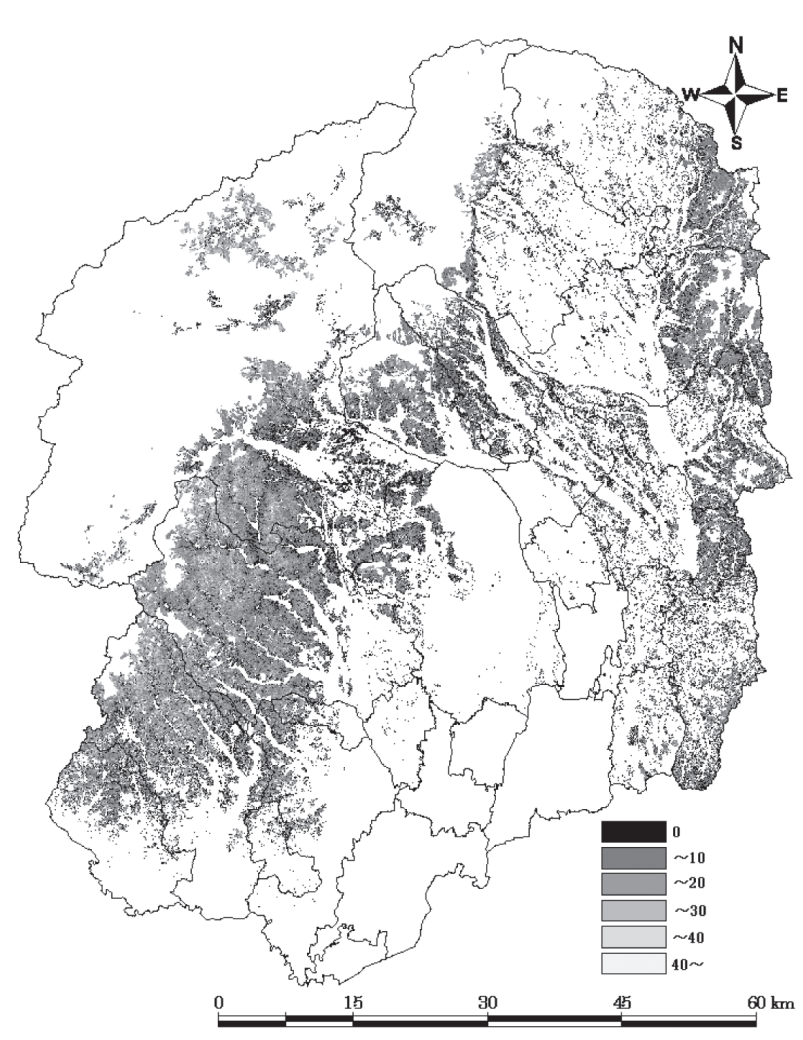

図 3 林地傾斜（度）

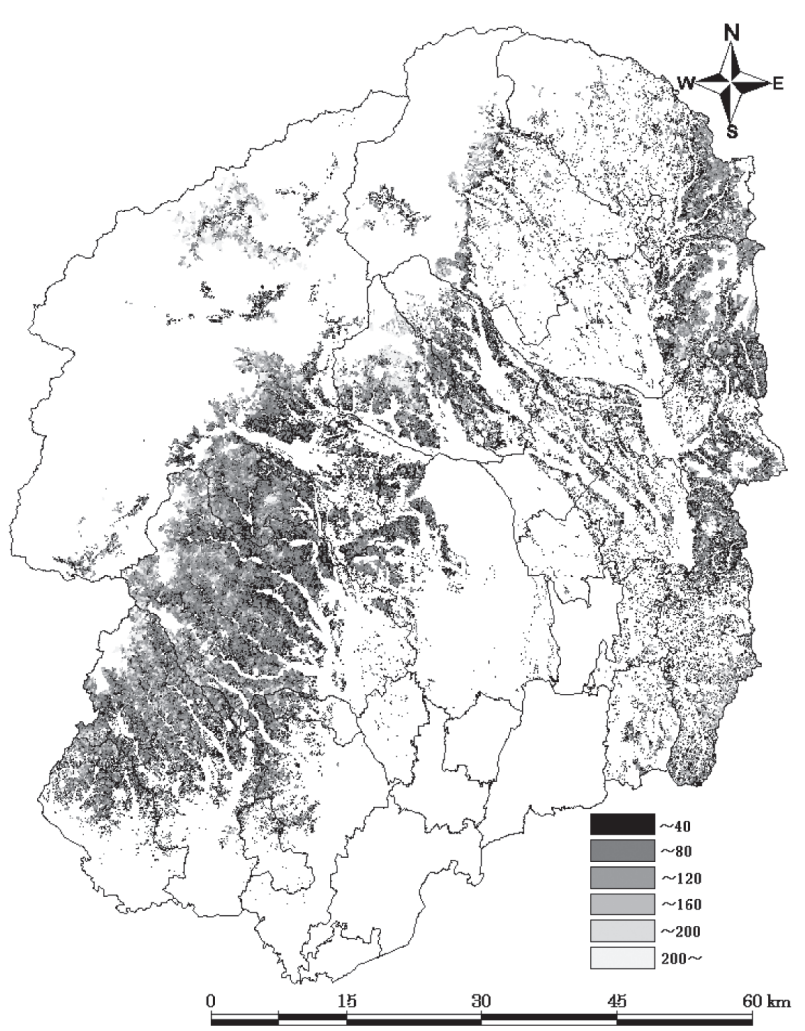

図 4 搬出距離 $(m)$

表 3 収穫作業システムと採用森林組合（枠内：林地残材収穫直接費計上部分）

\begin{tabular}{|c|c|c|c|c|c|}
\hline & (1) & (2) & (3) & (4) & (5) \\
\hline 収穫作業システム & 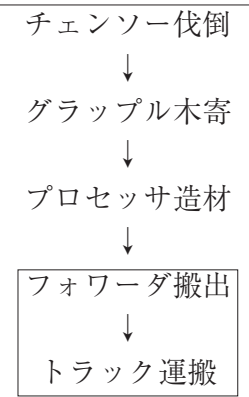 & \begin{tabular}{|c} 
チェンソー伐倒 \\
$\downarrow$ \\
チェンソー造材 \\
$\downarrow$ \\
スイングヤーダ集材 \\
$\downarrow$ \\
フォワーダ搬出 \\
$\downarrow$ \\
トラック運搬 \\
\end{tabular} & $\begin{array}{c}\text { チェンソー伐倒 } \\
\downarrow \\
\text { チェンソー造材 } \\
\downarrow \\
\qquad \\
\text { グラップル木寄 } \\
\downarrow \\
\text { フォワーダ搬出 } \\
\downarrow \\
\text { トラック運搬 }\end{array}$ & $\begin{array}{c}\text { チェンソー伐倒 } \\
\downarrow \\
\text { チェンソー造材 } \\
\downarrow \\
\text { グラップル木寄 } \\
\downarrow \\
\text { トラック運搬 }\end{array}$ & $\begin{array}{c}\text { チェンソー伐倒 } \\
\downarrow \\
\text { グラップル木寄 } \\
\downarrow \\
\text { チェンソー造材 } \\
\downarrow \\
\text { フォワーダ搬出 } \\
\downarrow \\
\text { トラック運搬 }\end{array}$ \\
\hline $\begin{array}{c}\text { 収穫作業システム } \\
\text { 採用森林組合 }\end{array}$ & $\begin{array}{c}\text { 日光地区森林組合 } \\
\text { 鹿沼市森林組合 } \\
\text { 粟野森林組合 } \\
\text { みかも森林組合 } \\
\text { 那須南森林組合 }\end{array}$ & $\begin{array}{c}\text { 日光地区森林組合 } \\
\text { 鹿沼市森林組合 } \\
\text { 粟野森林組合 } \\
\text { みかも森林組合 }\end{array}$ & $\begin{array}{c}\text { 那須塩原市森林組合 } \\
\text { 大田原森林組合 } \\
\text { たかはら森林組合 } \\
\text { 芳賀地区森林組合 }\end{array}$ & 栗山森林組合 & $\begin{array}{c}\text { 宇都宮市森林組合 } \\
\text { 那須町森林組合 } \\
\text { たかはら森林組合 }\end{array}$ \\
\hline
\end{tabular}

\section{表 4 各森林組合管轄地域}

\begin{tabular}{ll}
\hline \multicolumn{1}{c}{ 森林組合 } & \multicolumn{1}{c}{ 管轄地域 } \\
\hline 那須塩原市森林組合 & 那須塩原市 (旧黒磯市・旧西那須野町) \\
栗山森林組合 & 日光市 (旧栗山町) \\
宇都宮市森林組合 & 宇都宮市 \\
鹿沼市森林組合 & 鹿沼市 (旧鹿沼市) \\
日光地区森林組合 & 日光市 \\
粟野森林組合 & 鹿沼市 (旧粟野市), 西方町 \\
大田原森林組合 & 大田原市 \\
那須町森林組合 & 那須町 \\
たかはら森林組合 & 那須塩原市(旧塩原町), 矢板市, 塩谷 \\
みかも森林組合 & 町, さくら市 \\
み佐野市, 足利市, 栃木市, 岩舟町 \\
那須南森林組合 & 那珂川町, 那須烏山市 \\
芳賀地区森林組合 & 茂木町, 市貝町, 益子町 \\
\hline
\end{tabular}

合を，表 4 に各森林組合の管轄地域を示す。また，収穫作業 システムが 2 種類ある場合は，最大傾斜の急な小班から，聞 き取り調査から得た面積割合まで，急傾斜地に適すると思わ れる収穫作業システムを割り振った。この面積割合は, 森林 組合の管轄地域 (表 4 ) 毎に, 今回対象としている平成 20 年 度に間伐作業が行われた全森林面積を $100 \%$ として設定した值 である。急傾斜地に適用した収穫作業システムは, (2)スイン グヤーダ集材, (5)グラップル全木木寄である。表 5 に収穫作 業システムが 2 種類ある森林組合毎に, 傾斜と収穫作業シス テムの設定，およびその振り分けに用いた面積割合を示す。図 5 に収穫作業システム区分の結果を示す。 
表 5 収穫作業システム配分割合

\begin{tabular}{|c|c|c|c|c|c|c|c|c|c|c|}
\hline 森林組合 & \multicolumn{2}{|c|}{ 鹿沼市森林組合 } & \multicolumn{2}{|c|}{ 日光地区森林組合 } & \multicolumn{2}{|c|}{ 粟野森林組合 } & \multicolumn{2}{|c|}{ たかはら森林組合 } & \multicolumn{2}{|c|}{ みかも森林組合 } \\
\hline 傾斜 & 緩 & 急 & 緩 & 急 & 緩 & 急 & 緩 & 急 & 緩 & 急 \\
\hline 収穫作業システム & (1) & (2) & (1) & (2) & (1) & (2) & (3) & (5) & (1) & (2) \\
\hline 面積割合（\%） & 50 & 50 & 60 & 40 & 50 & 50 & 70 & 30 & 50 & 50 \\
\hline
\end{tabular}

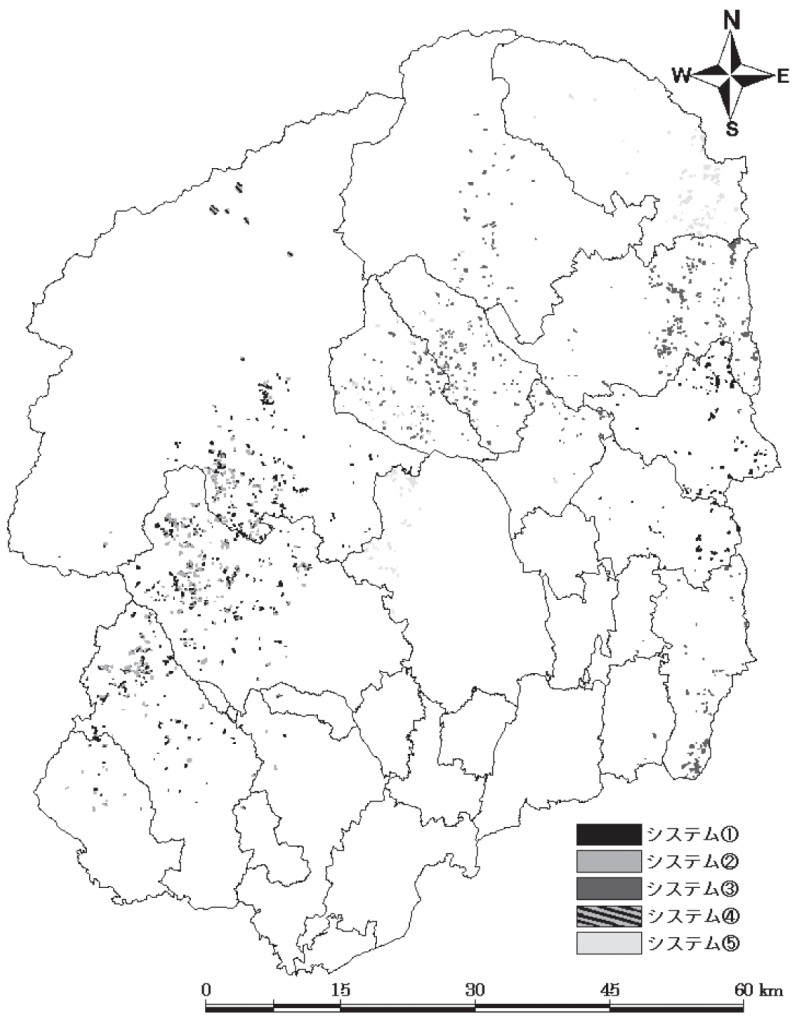

図 5 収穫作業システム分布図（ポイントを約 10 倍で強調）

さらに，グラップルでの木寄を行っている森林組合につい ては，ウィンチを用いた木寄と，グラップルを用いた直接木 寄を，最大傾斜の急な小班から面積割合 $2: 8$ で配分した。こ の面積割合は，グラップルでの木寄を行っている県内の $2 つ$ の森林組合に聞き取った值で，今回はこの值を全該当森林組 合に用いた。

機械規格についても聞き取りや，過去の調査記録などを参 考に森林組合毎に設定した。林地残材収穫直接費として計上 の対象としたフォワーダ，スイングヤーダ，グラップルにつ いて，森林組合毎の規格設定を表 6 に示す。また，中型もし くは小型として想定した各機械は，フォワーダ積載量が中型 で $3.5 \mathrm{~m}^{3}$ ，小型で $2.5 \mathrm{~m}^{3}$ ，スイングヤーダおよびグラップル のバケット容量がそれぞれ中型で $0.45 \mathrm{~m}^{3}, 0.25 \mathrm{~m}^{3}$, 小型で $0.25 \mathrm{~m}^{3}, 0.15 \mathrm{~m}^{3}$ とした。

今回は，伐倒造材までにかかる費用および作業路作設費，架 設撤去費は，用材搬出費用として林地残材収穫直接費には計 上せず，造材後の林地残材発生時から林地残材収穫直接費と して計上した。表 3 に林地残材収穫直接費として計上した作 業部分を示す。また，小班が道路と重なる 0.25 haの小面積の 場合は，搬出作業は不要と仮定して，グラップルによるはい 積み, トラック運搬のみを林地残材収穫直接費とした。さら
表 6 使用機械の規格設定

\begin{tabular}{lccc}
\hline \multicolumn{1}{c}{ 森林組合 } & フォワーダ & スイングヤーダ グラップル \\
\hline 那須塩原市森林組合 & 小型 & - & 小型 \\
栗山森林組合 & - & - & 中型 \\
宇都宮市森林組合 & 小型 & - & - \\
鹿沼市森林組合 & 小型 & 小型 & - \\
日光地区森林組合 & 小型 & 中型 & - \\
粟野森林組合 & 小型 & 小型 & - \\
大田原森林組合 & 小型 & - & 中型 \\
那須町森林組合 & 小型 & - & - \\
たかはら森林組合 & 中型 & - & 小型 \\
みかも森林組合 & 小型 & 小型 & - \\
那須南森林組合 & 小型 & - & - \\
芳賀地区森林組合 & 中型 & - & 小型 \\
\hline
\end{tabular}

※フォワーダ積載量: 中型 $2.38 \mathrm{t}\left(3.50 \mathrm{~m}^{3}\right)$, 小型 $1.70 \mathrm{t}\left(2.50 \mathrm{~m}^{3}\right)$ ※スイングヤーダバケット容量：中型 $0.45 \mathrm{~m}^{3}$, 小型 $0.25 \mathrm{~m}^{3}$ ※グラップルバケット容量：中型 $0.25 \mathrm{~m}^{3}$ ，小型 $0.15 \mathrm{~m}^{3}$

に副作業費として土場作設費も計上した。

表 7 に使用機械の林地残材収穫直接費計算式を示す。なお, 計算式内の集材距離 Lyは, スイングヤーダ $50 \mathrm{~m}$, 木寄距離 Lsは, グラップル中型 $15 \mathrm{~m}$, 小型 $10 \mathrm{~m}$ とした。また, みか も森林組合で平成 20 年に行われた調査において，間伐によっ て発生した全木を末木枝条含めて搬出した場合の生産性が， 幹部のみを搬出した場合の生産性の $48 \%$ 程度であったため, 今回の計算式でも同等の変更を加えた ${ }^{7)}$ 。

\section{6 林地残材収穫可能量の推定}

林地残材の買取価格をパルプ材の価格などを参考に 3,000 円/t，補助金，地域通貨11などによる上乗せを考慮して 6,000 円/t，また，電力固定価格買取制度の検討状況 ${ }^{12)}$ などを参考 に10,000円/tと設定し, 林地残材による収入を算出, 林地残 材収穫直接費との収支比較を小班毎に行い，収支プラスとな る小班からの林地残材発生量を林地残材収穫可能量とした。

\section{7 林地残材発生量の補正}

シミュレーションでは, $50 \mathrm{~m} \times 50 \mathrm{~m}$ のラスターデータに 変換した際に，0.25 haのメッシュに複数の小さい小班が存在 している場合，自動的に 1 つの小班に取りまとめられ，小班 が潰れてしまったことや，GIS上での自動によるリンク付けの 際に，枝番がある小班を判別できない場合などにより，施業 履歴に記載されている全デー夕数に比べ, データ数の減少が 見られた。

また, 主伐に係わる施業履歴が未整備であるため, 小班単 位によるシミュレーションが不可能であった。そこで主伐で 
表 7 使用機械，規格毎の林地残材収穫直接費計算式 $\left(円 / \mathrm{m}^{3}\right)$

\begin{tabular}{|c|c|c|c|c|}
\hline 使用機械・作業工程 & \multicolumn{2}{|c|}{ 規格 } & 1小班あたり林地残材収穫直接費 $\left(\right.$ 円 $\left./ \mathrm{m}^{3}\right)$ & 備考 \\
\hline フォワーダ・搬出 & \multicolumn{2}{|c|}{$\begin{array}{l}\text { 中型 } \\
\text { 小型 }\end{array}$} & $\begin{array}{l}1.011 L f+866 \\
1.348 L f+808\end{array}$ & $\begin{array}{c}\text { 日本森林技術協会 }(2010)^{8)} \\
\text { 同上 }\end{array}$ \\
\hline \multirow{4}{*}{ スイングヤーダ・集材 } & \multirow[t]{2}{*}{ 中型 } & 下荷 & $16.193 \times\left\{\left(1 / 1.26 e^{-0.003 \theta}+1 / 1.26 e^{-0.272-0.014 \theta}\right) \times L y+208.9\right\}$ & $\begin{array}{c}\text { 澤口 }(1996)^{9)}, \\
\text { 日本森林技術協会 }(2010)^{8)}\end{array}$ \\
\hline & & 上荷 & $16.193 \times\left\{\left(1 / 1.26 e^{-0.00345 \theta}+1 / 1.26 e^{-0.272-0.0504 \theta}\right) \times L y+208.9\right\}$ & 同上 \\
\hline & \multirow{2}{*}{ 小型 } & 下荷 & $13.563 \times\left\{\left(1 / 1.26 e^{-0.003 \theta}+1 / 1.26 e^{-0.272-0.014 \theta}\right) \times L y+208.9\right\}$ & 同上 \\
\hline & & 上荷 & $13.563 \times\left\{\left(1 / 1.26 e^{-0.00345 \theta}+1 / 1.26 e^{-0.272-0.0504 \theta}\right) \times L y+208.9\right\}$ & 同上 \\
\hline \multirow{4}{*}{$\begin{array}{l}\text { グラップル・木寄 } \\
\text { (ウィンチ引き寄せ) }\end{array}$} & \multirow{2}{*}{ 中型 } & 下荷 & $15.13 \times\left\{\left(1 / 1.26 e^{-0.035 \theta}+1 / 1.26 e^{-0.205-0.053 \theta}\right) \times L S+44.36\right\}$ & 日本森林技術協会 $(2010)^{8)}$ \\
\hline & & 上荷 & $15.13 \times\left\{\left(1 / 1.26 e^{-0.0308 \theta}+1 / 1.26 e^{-0.205-0.04187 \theta}\right) \times L S+44.36\right\}$ & 同上 \\
\hline & \multirow{2}{*}{ 小型 } & 下荷 & $18.96 \times\left\{\left(1 / 1.26 e^{-0.057 \theta}+1 / 1.26 e^{-0.2-0.078 \theta}\right) \times L S+41.51\right\}$ & 同上 \\
\hline & & 上荷 & $18.96 \times\left\{\left(1 / 1.26 e^{-0.0536 \theta}+1 / 1.26 e^{-0.2-0.064 \theta}\right) \times L S+41.51\right\}$ & 同上 \\
\hline \multirow{2}{*}{$\begin{array}{l}\text { グラップル・木寄 } \\
\text { (グラップル引き出し) }\end{array}$} & \multicolumn{2}{|c|}{ 中型 } & 3,002 & 同上 \\
\hline & \multicolumn{2}{|c|}{ 小型 } & 2,265 & 同上 \\
\hline \multicolumn{3}{|c|}{ グラップル・はい積み } & 270 & 全国林業改良普及協会10) \\
\hline \multicolumn{3}{|c|}{8 t トラック・運搬 } & $0.076 L t+778$ & 澤口(1996) ${ }^{9)}$ \\
\hline \multicolumn{3}{|c|}{ 土場作設費 } & $165.224 H \times L r+7,211$ & 全国林業改良普及協会 ${ }^{10)}$ \\
\hline
\end{tabular}

$L f$ : 搬出距離 $(\mathrm{m}), L y$ : 集材距離 $(\mathrm{m}), L \mathrm{~s}$ : 木寄距離 $(\mathrm{m}), L t$ : 運搬距離 $(\mathrm{m}), \theta$ : 林地傾斜 (度), $H \times L r:$ 林地残材発生量 $\left(\mathrm{m}^{3}\right)$ 集材距離は，スイングヤーダ $50 \mathrm{~m}$ ，木寄距離は，グラップル（中型） $15 \mathrm{~m} ，$ グラップル (小型) $10 \mathrm{~m}$ とす。

は，地域森林計画策定のために推定した平成20年度における 県内での主伐（皆伐）材積総量を，主伐林分が翌年度に植栽 されたものと仮定して, 森林GISの施業履歴データの造林 (植 林）実績に基づいて各市町に按分し，搬出率 Er（スギ123\%， ヒノキ $124 \%$ の平均值 $123.4 \%$ ）を乗じて各市町からの全発生 量 $H\left(\mathrm{~m}^{3}\right)$ を求め，これに材種率 $(\mathrm{C} \cdot \mathrm{D}$ 材 $) L r$ と容積比重 $G r$ を用いて各市町からの林地残材発生量を算出した。なお，材 種率 $(\mathrm{C} \cdot \mathrm{D}$ 材 $) L r$ ，材種率 $(\mathrm{A} \cdot \mathrm{B}$ 材）は蓄積に対してそれ ぞれ $25 \% ， 75 \%$ と設定したため，地上部材積に対する材種率 は表 1 の通りとなる。

以上のことから, 今回の解析では, 解析から除外された小 班及び主伐に伴う林地残材発生量を含む各市町の全林地残材 発生量とシミュレーションで算出された全林地残材発生量の 比 (補正係数) を用いて，小班毎の収穫費用は変化させずに， 小班の林地残材発生量を補正した。

\section{4. 結 果}

栃木県全域に拈いて，平成20年度の施業履歴を用いて林地 残材発生量を推定したところ, 最小の小班で $3 \mathrm{t}$, 最大の小班 で $3,853 \mathrm{t}$ ，平均的には小班あたり $78 \mathrm{t}$ 程度が見込まれた（図 6 )。各市町における林地残材収穫直接費を，買取価格の設定 でクラス分けした分布図を図 $7 ， 8$ に示す。また，各市町に 拈ける林地残材収穫可能量と，その全体に対する割合を表 8 にまとめる。林地残材買取価格 3,000 円/t では収穫可能量は $595 \mathrm{t}$ と少なかったが，林地残材買取価格を 6,000 円/tに設定 することにより，那須塩原市のペレット工場需要量 3,000 tを 那須町, 大田原市, 那須塩原市の収穫可能量で賄うことがで き, 栃木県全域の収穫可能量は佐野市と鹿沼市のチップ生産 工場の林地残材年間需要量 $6,000 \mathrm{t}$ とチップ年間生産量 12,000 $\mathrm{m}^{3}$ を十分に賄うことができる量と試算された。さらに林地残 材買取価格を10,000円/tに設定した場合には，佐野市の木質 バイオマスを主燃料とする発電所の木質バイオマス年間需要 量 100,000 tをも賄うことができる収穫可能量となり, 電力固 定価格買取制度の影響の大きさが窥える。

また，各市町についてみると，林地残材買取価格6,000円/ tでは，市内に工場のある佐野市とその周辺の足利市，岩舟町 で収穫可能割合が $40 \%$ 以上となったが，同じく市内に工場が あり, 収穫作業システムも佐野市と同様の鹿沼市では $37 \%$ と なっていた。これは佐野市に比べ鹿沼市が広く，佐野市の平 均運搬距離が $15.8 \mathrm{~km}$ であるのに対し，鹿沼市の平均運搬距離 は20.3 kmと長いためだと考えられる。特に収穫可能割合が大 きくなったのは，宇都宮市と西方町であった。この 2 市町は， 収穫作業システム（表 3 ) が(1)もしくは(5)の全木木寄システ ムで，林地残材収穫費用としてはフォワーダ搬出とトラック 運搬のみが計上され低コストであった。

10,000円/tで収穫可能割合が50\%を超えた市町は，宇都宮 市, 足利市, 佐野市, 那須烏山市, 西方町, 岩舟町, 塩谷町, 那珂川町であった。市内に工場があるにも関わらず，佐野市 $50 \%$ ，鹿沼市 $49 \%$ とあまり高くならなかったのは，収穫作業 システム(2)のスイングヤーダの短幹材集材が割高になったた めである。収穫作業システム（表 3 ）が(1)もしくは(5)の全木 木寄システムは有利で，塩谷町が $65 \%$ と高い割合になったの は，たかはら森林組合管轄地域（表 4 ）の中でも，システム (5)に分類された小班が多かったためだと考えられる。那珂川 町や那須烏山市のように，やや遠い市町でも $90 \%$ 以上となっ たのは，(1)の全木木寄システムであり，買取価格が10,000円/ $\mathrm{t}$ を超えれば，平均運搬距離 $55.9 \mathrm{~km}$, 平均運搬費用 7,396 円/ tを賄うことができるためである。しかし，(5)の全木木寄シス テムであっても，那須町，那須塩原市，大田原市といった遠 距離では平均運搬距離 $64.9 \mathrm{~km}$, 平均運搬費用 8,396 円/ $\mathrm{t}$ とな 

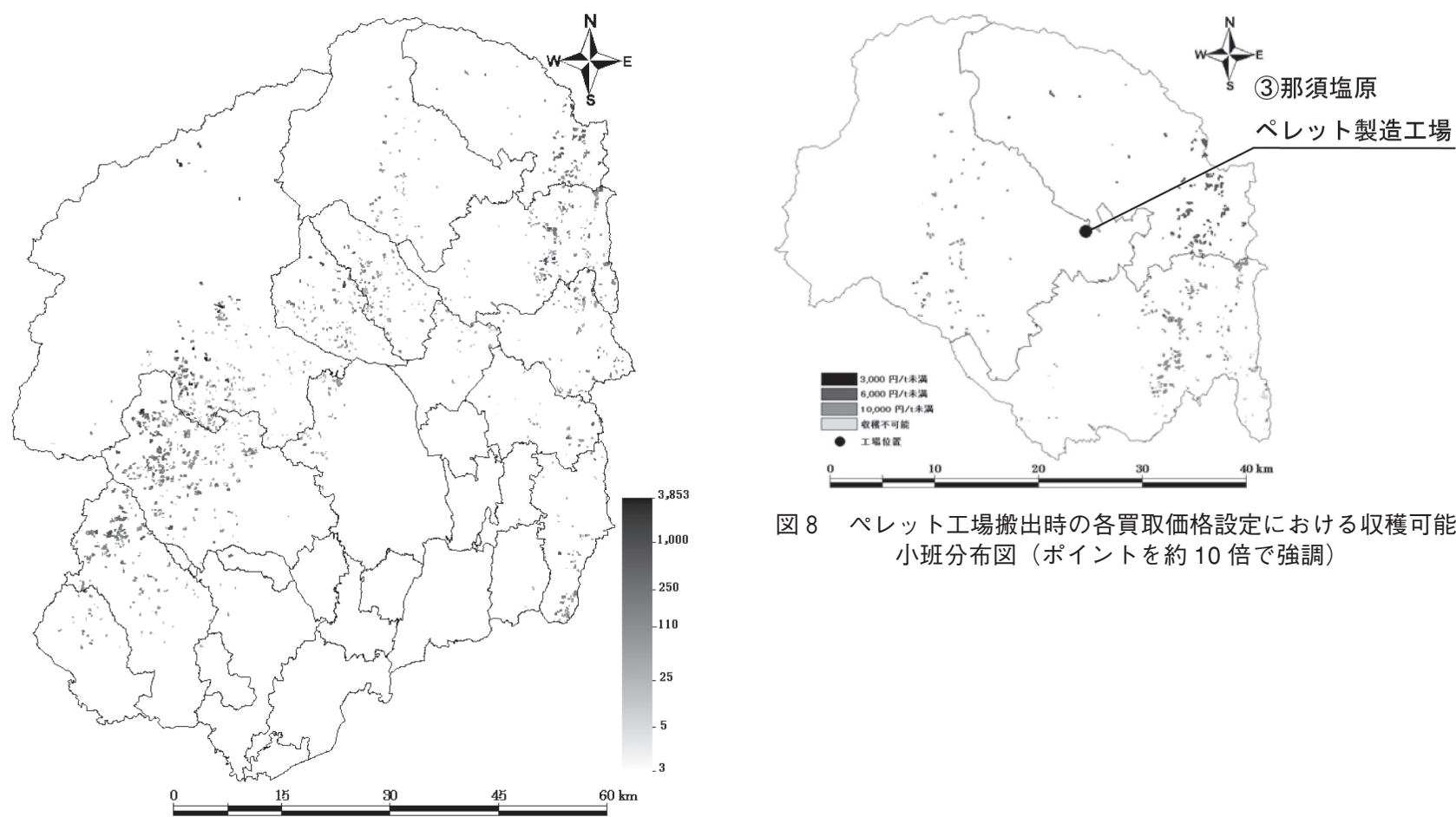

図 8 ペレット工場搬出時の各買取価格設定における収穫可能 小班分布図（ポイントを約 10 倍で強調）

図 6 推定林地残材発生量（t）（ポイントを約 10 倍で強調）

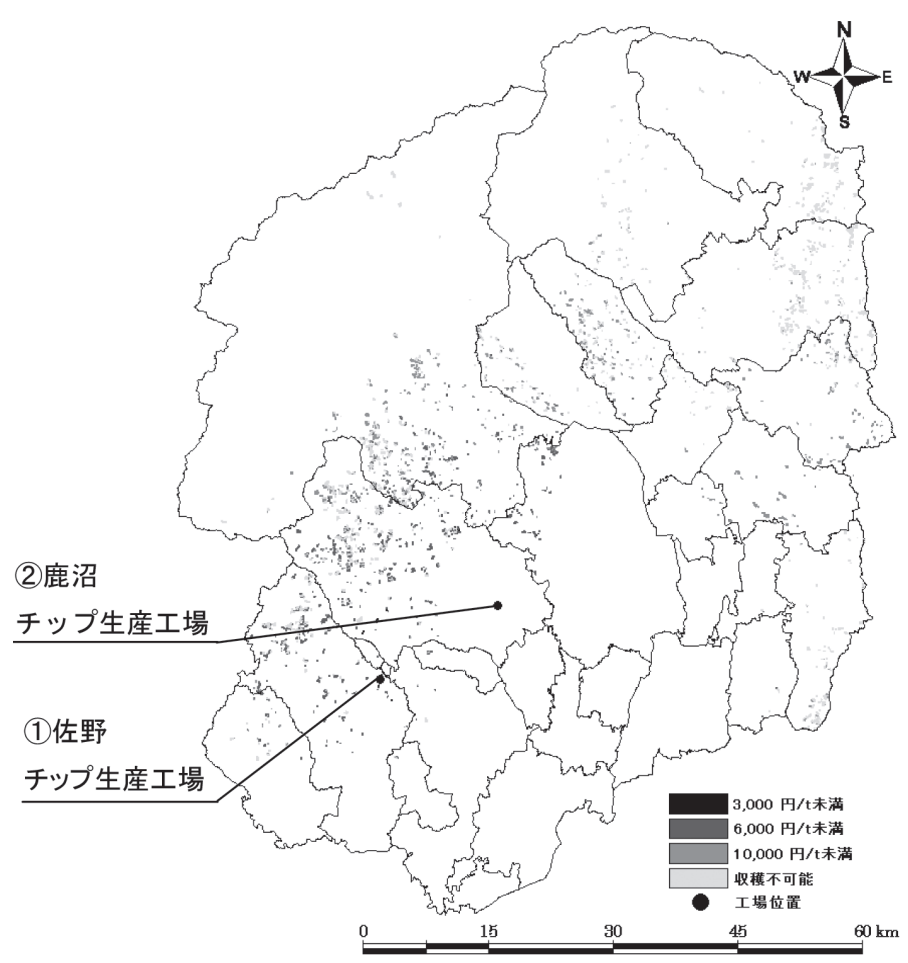

図 7 チップ生産工場搬出時の各買取価格設定における収穫可能小班分布図（ポイントを約 10 倍で強調） 
表 8 市町別林地残材収穫可能量

\begin{tabular}{|c|c|c|c|c|c|c|c|c|}
\hline \multicolumn{2}{|c|}{ 林地残材買取価格 } & \multicolumn{2}{|c|}{3,000 円 $/ t$} & \multicolumn{2}{|c|}{6,000 円 $/ t$} & \multicolumn{2}{|c|}{10,000 円 $/ \mathrm{t}$} & \multirow[b]{2}{*}{ 搬出先内訳 } \\
\hline 市町村 & \begin{tabular}{|c|} 
推定林地残材 \\
発生量 $(\mathrm{t})$
\end{tabular} & $\begin{array}{c}\text { 収穫可能量 } \\
(\mathrm{t})\end{array}$ & $\begin{array}{l}\text { 収穫可能 } \\
\text { 割合 }(\%)\end{array}$ & $\begin{array}{c}\text { 収穫可能量 } \\
(\mathrm{t})\end{array}$ & $\begin{array}{l}\text { 収穫可能 } \\
\text { 割合 }(\%)\end{array}$ & $\begin{array}{c}\begin{array}{c}\text { 収穫可能量 } \\
(\mathrm{t})\end{array} \\
\end{array}$ & $\begin{array}{l}\text { 収穫可能 } \\
\text { 割合 }(\%)\end{array}$ & \\
\hline 宇都宮市 & $6,547.04$ & 95.46 & 1.46 & $5,129.25$ & 78.34 & $6,545.04$ & 99.97 & 鹿沼チップ生産工場 \\
\hline 足利市 & $3,762.44$ & 0.00 & 0.00 & $1,544.87$ & 41.06 & $2,058.01$ & 54.70 & 佐野チップ生産工場 \\
\hline 栃木市 & 184.96 & 0.00 & 0.00 & 69.74 & 37.70 & 69.74 & 37.70 & 佐野チップ生産工場 \\
\hline 佐野市 & $44,654.92$ & 92.66 & 0.21 & $21,744.60$ & 48.69 & $22,371.26$ & 50.10 & 佐野チップ生産工場 \\
\hline \multirow{2}{*}{ 鹿沼市 } & \multirow{2}{*}{$81,908.04$} & 124.53 & 0.15 & $12,973.78$ & 15.84 & $14,929.45$ & 18.23 & 佐野チップ生産工場 \\
\hline & & 180.19 & 0.22 & $17,606.08$ & 21.49 & $24,802.58$ & 30.28 & 鹿沼チップ生産工場 \\
\hline 小計 & $81,908.04$ & 304.72 & 0.37 & $30,579.86$ & 37.33 & $39,732.04$ & 48.51 & \\
\hline \multirow{2}{*}{ 日光市 } & \multirow{2}{*}{$66,567.92$} & 0.00 & 0.00 & 0.77 & 0.001 & 67.91 & 0.10 & 佐野チップ生産工場 \\
\hline & & 1.39 & 0.002 & $9,604.18$ & 14.43 & $24,141.79$ & 36.27 & 鹿沼チップ生産工場 \\
\hline 小計 & $66,567.92$ & 1.39 & 0.002 & $9,604.94$ & 14.43 & $24,209.70$ & 36.37 & \\
\hline \multirow{2}{*}{ 大田原市 } & \multirow{2}{*}{$32,546.84$} & 0.00 & 0.00 & 0.00 & 0.00 & 214.07 & 0.66 & 鹿沼チップ生産工場 \\
\hline & & 71.94 & 0.22 & 836.09 & 2.57 & 836.09 & 2.57 & 那須塩原ペレット工場 \\
\hline 小計 & $32,546.84$ & 71.94 & 0.22 & 836.09 & 2.57 & $1,050.16$ & 3.23 & \\
\hline 矢板市 & $12,404.56$ & 0.00 & 0.00 & 154.09 & 1.24 & $6,161.07$ & 49.67 & 鹿沼チップ生産工場 \\
\hline \multirow{2}{*}{ 那須塩原市 } & \multirow{2}{*}{$4,867.44$} & 0.00 & 0.00 & 0.00 & 0.00 & 544.80 & 11.19 & 鹿沼チップ生産工場 \\
\hline & & 28.80 & 0.59 & 215.94 & 4.44 & 215.94 & 4.44 & 那須塩原ペレット工場 \\
\hline 小計 & $4,867.44$ & 28.80 & 0.59 & 215.94 & 4.44 & 760.75 & 15.63 & \\
\hline さくら市 & $1,958.40$ & 0.00 & 0.00 & 0.00 & 0.00 & 437.82 & 22.36 & 鹿沼チップ生産工場 \\
\hline 那須烏山市 & $5,301.28$ & 0.00 & 0.00 & 8.92 & 0.17 & $5,284.67$ & 99.69 & 鹿沼チップ生産工場 \\
\hline 西方町 & $1,250.52$ & 0.00 & 0.00 & 741.75 & 59.32 & 741.75 & 59.32 & 鹿沼チップ生産工場 \\
\hline 益子町 & 187.68 & 0.00 & 0.00 & 15.09 & 8.04 & 15.09 & 8.04 & 鹿沼チップ生産工場 \\
\hline 茂木町 & $10,093.24$ & 0.00 & 0.00 & 0.00 & 0.00 & $1,958.38$ & 19.40 & 鹿沼チップ生産工場 \\
\hline 市貝町 & 153.00 & 0.00 & 0.00 & 51.53 & 33.68 & 51.53 & 33.68 & 鹿沼チップ生産工場 \\
\hline 岩舟町 & 85.00 & 0.00 & 0.00 & 36.87 & 43.37 & 45.27 & 53.26 & 佐野チップ生産工場 \\
\hline 塩谷町 & $16,966.00$ & 0.00 & 0.00 & 729.77 & 4.30 & $11,040.90$ & 65.08 & 鹿沼チップ生産工場 \\
\hline 那須町 & $30,197.44$ & 0.00 & 0.00 & $2,118.42$ & 7.02 & $2,118.42$ & 7.02 & 那須塩原ペレット工場 \\
\hline 那珂川町 & $16,531.48$ & 0.00 & 0.00 & 0.00 & 0.00 & $14,010.70$ & 84.75 & 鹿沼チップ生産工場 \\
\hline 計 & $336,168.20$ & 594.98 & 0.18 & $73,581.73$ & 21.89 & $138,662.30$ & 41.25 & \\
\hline
\end{tabular}

り，買取価格 10,000 円/tでも賄うことはできなかった。

\section{5. おわりに}

本調査では，栃木県全域において，平成20年度の施業履歴 を用いることにより，単年度の林地残材発生量を推定し，聞 き取り調査より各地域に沿った作業システムを設定，費用算 定式を用いて収穫費用を試算，想定した買取価格と比較し，経 済性が成り立つ林地から搬出される林地残材を収穫可能量と して推定した。その結果，林地残材買取価格を補助金による 上乗せなどにより 6,000 円/ tに設定することにより，今回，想 定した 3 箇所の林地残材利用施設の年間需要量を，また，電 力固定価格買取制度などにより林地残材買取価格が 10,000 円/tと設定された場合には，佐野市の木質バイオマスを主燃 料とする発電所の木質バイオマス年間需要量をも賄うことが できる収穫可能量となると試算された。

作業システムに関しては林地残材収穫費用がフォワーダ搬 出, トラック運搬のみとなる全木木寄システムが有利であり, このシステムを活用するためには林業機械が走行することの できる路網の整備が必要である。また，このシステムを活用 している森林組合では平均運搬距離が $55 \mathrm{~km}$ と長距離でも収
穫可能量が大きかった。ただし，運搬距離が $60 \mathrm{~km}$ を超える 森林組合では収穫可能量が少なかったため, 今回は林業現場 で広く利用されている積載量 8 トンのトラックを想定して, 収穫費用を試算したが (表 7 ), 今後は中間土場を設定して, 大型のトレーラなどに積み替えることなどにより，運搬効率 の向上を目指す必要があるだろう。

また，本調査に関しては用材搬出後に林地残材のみを搬出 することを想定して収支を試算したが，実際は用材搬出費用 とその収入による収支比較も行った上で，用材搬出と同時に 発生する林地残材を搬出することを想定して, 収穫可能量を 算出するほうが現実の施業に適していると考える。さらに筆 者らは，前報3)で栃木県佐野市において，用材搬出と同時に 発生する林地残材の収穫可能量を算出したが, 用材価格は林 地残材価格に比べ高いため，収支に与える影響が大きく，用 材価格が上がるにしたがって，用材収入で，林地残材費用を 賄える小班が増加し, 林地残材収穫可能量が増加すると試算 された。したがって，今回の施業履歴を用いた全県解析にお いても，用材搬出収支も考慮することにより林地残材収穫可 能量の増加が期待される。

施業履歴に関しては，とりまとめに多大な労力を要するこ 
とから，今回は平成 20 年度のみを用いたが，今後は他の年度 の施業履歴も活用して, 林地残材発生量及び収穫可能量の傾 向を分析する必要があるだろう。さらに，補助事業の記録を 元に整備されている施業履歴では, 主伐のように補助事業を 用いない作業の記録はなく, 今回の試算に適用することがで きなかった。今後，伐採作業の届出などを基にした主伐作業 の記録の活用も検討する必要があるだろう。

\section{謝 辞}

本業務を進めるにあたり，ご協力いただいた栃木県環境森 林部林業振興課，杤木県森林組合連合会に厚く感謝の意を表 します。

\section{文 献：References}

1）栃木県庁，平成 21 年度版栃木県森林 - 林業統計書，（栃木 県庁), (2009) : Tochigi Prefectural Government, Forest and forestry statistics of Fiscal year 2009 in Tochigi Prefectural, (Tochigi Prefectural Government), (2009)

2) 栃木県庁，平成 21 年度とちぎの元気な森づくり県民税事 業評価報告書，(栃木県庁)，（2010）：Tochigi Prefectural Government, Tochigi no genkina moridukuri prefectural tax business evaluation report of Fiscal year 2009, (Tochigi Prefectural Government), (2010)

3）山口鈴子，有賀一広，村上文美，斎藤仁志，伊藤要，日工 ネ誌，89(10), 982 (2010) : Yamaguchi, R., Aruga, K., Murakami, A., Saito, M., Ito, K., J. Jpn. Inst. Energy, 89 (10), 982 (2010)

4）山口鈴子，有賀一広，機械化林業，672，1（2009）： Yamaguchi, R., Aruga, K., KikaikaRingyo, 672, 1(2009)

5）下野新聞，2月14日，11面，(2009)：Shimotsuke
Shinbun, 14th of February, 11 (2009)

6) 温室効果ガスインベントリオフィス編, 日本国温室効果ガ スインベントリ報告書，(国立環境研究所），p． 190 (2006) : Greenhouse Gas Inventory Office of Japan, Greenhouse Gas Inventory report in Japan, (National Institute for Environmental Studies, Japan), p. 190 (2006)

7）みかも森林組合，住友大阪セメント「木質バイオマス資源 調達に関する調査報告(非公開)，(みかも森林組合)，p. 11 (2008) : Mikamo Forest Owner's Association, Sumitomo Osaka Cement Company Research report on extracting "forest biomass resources", (Mikamo Forest Owner's Association), p. 11(2008)

8）日本森林技術協会, 低コスト作業システム構築事業報告 書，(日本森林技術協会)，p. 20，(2010）：Japan Forest Technology Association, Low-cost system construction business report, (Japan Forest Technology Association), p. 20, (2010)

9）澤口勇雄，森林総合研究所研究報告，372, p. 103(1996)： Sawaguchi, I., Bull. For. \& For. Prod. Res. Inst., 372, p. 103 (1996)

10）全国林業改良普及協会編，機械化のマネジメント，(全国 林業改良普及協会)，p. 226(2001)：ZenkokuRingyo KairyoFukyuKyokai, Kikaika no Management, (Zenkoku RingyoKairyoFukyuKyokai), p. 226 (2001)

11）日本林業調査会，林政ニュース，409, 14(2011)：Japanese forestry investigation committee, Rinsei News, 409, 14(2011)

12）日本林業調査会，林政ニュース，405, 7 (2011)：Japanese forestry investigation committee, Rinsei News, 405, 7 (2011) 